\title{
Political Communication of Ahok in Demolishing Slums to Normalise River Ciliwung in Jakarta
}

\author{
NUR KHOLISOH \\ YUVENTUS NEWIN BYLMORENO \\ Universitas Mercu Buana Jakarta, Indonesia
}

\begin{abstract}
The relocation of residents of Kampung Pulo in East Jakarta to make way for the normalisation of River Ciliwung ended in chaos. The chaos was inseparable from the policy of the then governor of the Special Capital Province of Jakarta, Basuki "Ahok" Tjahaja Purnama, known for his harsh and temperamental attitude. This research aims to study the political messages of Governor Ahok in applying a policy to the normalisation of River Ciliwung. The theory of symbolic interaction, the theory of coordinated management of meaning, the theory of conflict, and the theory of speech act are used to analyse the political messages of Governor Ahok and the responses of Kampung Pulo residents to the political messages. This research uses a qualitative approach with a case study method. Research data were collected through in-depth interviews, video recordings and broadcasts of news. This research found inconsistency of the political messages, thus disrupting the implementation of the policy to normalise River Ciliwung. The political messages of Ahok contain euphemism: "our brothers who haven't had any luck"; metaphor "no rent but maintenance fees"; and labeling "illegal residents". The residents responded to the political messages in the context of episode, identity, relation and culture. Consequently, both sides were locked in their respective meaning. The residents insisted on demanding compensation for the relocation of the residents as legal ones, while Ahok was confined to the meaning of illegal residents. The dispute culminated in a clash between Kampung Pulo residents and government apparatuses on August 20, 2015.
\end{abstract}

Keywords: Political communication, demolition, public policy, conflict, river Ciliwung.

\section{INTRODUCTION}

The Provincial Government of the Special Capital Region of Jakarta or Jakarta has made an effort to deal with floods through the Jakarta Urgent Flood Mitigation Project (JUFMP)/Jakarta Emergency Dredging Initiative (JEDI) along with the World Bank by normalising River Ciliwung that flows through Jakarta City. The river flow must be normalised by relocating residents living along the banks of River Ciliwung.

As a follow-up to this project, the Provincial Government of Jakarta issued Decision of the Governor of Jakarta No. 365 of 2014, which designates the location for the normalisation of the river spanning 19.8 kilometers from TB. Simatupang Street, Condet, to Manggarai Sluice Gate in South Jakarta and East Jakarta. The problem arose when the residents living there challenged the provincial government's intention to realise the river normalisation project.

The then Jakarta Governor Basuki Tjahaja Purnama remained adamant about evicting the residents living along the banks of the river. Ahok, as Governor Basuki is popularly called, is an "iron-fisted" leader as shown by his firm, harsh and temperamental personality.

Ahok previously served as deputy of Jakarta Governor Joko Widodo (Jokowi) for the 2012-2017 period. It was not until October 2014 that he took the helm of the Jakarta provincial government to replace Jokowi who was elected the president of the Republic of Indonesia. Since becoming governor, Ahok had actively carried out infrastructure 
development by demolishing slums, including Kampung Pulo in Kampung Melayu, Jatinegara Sub-district, East Jakarta.

Data from the Jakarta Legal Aid Foundation shows that throughout 2015 Ahok took 113 acts of forced demolition (Januardy \& Demadevina, 2016). Of the total, $84 \%$ were done unilaterally, thus inflicting losses on 8,145 households and 6,283 business units. The demolition in the era of Ahok is considered the most brutal one in the history of Jakarta because it involved violence, stigmatisation and even terror against evicted residents.

Actually, cases of demolition occurred not merely in the era of Ahok. In the era of Old Order regime, a residential area in Senayan was also demolished to make way for the construction of sports complex for the Asian Games 1962. At that time, President Soekarno directly got involved in the plan for the residential demolition by familiarising residents with the plan. The demolition ran peacefully without any resistance from the evicted residents.

In the era of New Order regime, the then Jakarta Governor, Ali Sadikin also carried out demolition, but it was done persuasively through dialogues without violence so that some of the residents voluntarily donated their land. Now, in the era of Governor Anies Bawesdan, the rearrangement of residential areas still continues, but it is done persuasively to avoid conflicts.

The higher number of conflicts that occurred during the demolition of residential areas in the era of Governor Ahok was inseparable from his harsh character and tendency to sacrifice the low-income people. This is evident from the demolition of various residential areas in Jakarta, including Kampung Luar Batang marked by chaos in 2016.

Some 4,000 personnel from the Jakarta Metropolitan Police, the Indonesian Military and the Public Order Agency were deployed to Kampung Luar Batang. They were equipped with water cannons to face the residents (BBC News Indonesia, 2016) who refused the demolition of their homes.

Ahok conducted one-sided demolition of residential areas without prior socialisation. In fact, democratic good governance is marked by public participation or involvement in making decisions and implementing public policies (Ahmadi, Rachmiatie, \& Nursyawal, 2019). Instead, Ahok questioned why the demolition of Kampung Akuarium, for instance, must be preceded by socialisation while the buildings there were built on land owned by Jakarta provincial government-owned company.

Without good communication between communicator and communicant, the messages conveyed will not be effective. The absence of good communication (Idris, 2018) or the lack of interaction may lead to communication crisis and emergency as what happened in Kampung Pulo.

The normalisation of River Ciliwung in Kampung Pulo by demolishing homes built along the banks of the river and relocating evicted residents to rented flats in Jatinegara was rejected and resisted. The residents were opposed to the demolition of their homes because Ahok paid no attention to their rights.

The residents of Kampung Pulo, filed a class action lawsuit with the State Administrative Court to annul the Demolition Order, while at the same time trying to hold dialogues with Ahok. The residents did not object to being relocated, provided there was a memorandum of agreement with Ahok. However, the demand came to a standstill, with both sides agreeing not to agree. 
The communication between both sides without agreement ended when the provincial government issued the third warning on August 6, 2015. The warning dealt a blow to the residents of Kampung Pulo amidst uncertainty about their fate. Even they were labeled "illegal residents".

The communication deadlock ended in a clash between the residents of Kampung Pulo and 2,150 personnel of the Military, Police and Public Order Agency conducting forced demolition of their homes. The pledge of the provincial government of Jakarta during Joko Widodo's term of office as governor of Jakarta to relocate humanly the residents of Kampung Pulo did not materialize.

Communication is present in public policies through various complex ways. Communication constraints in the implementation of public policies often cause an upheaval that has an adverse impact on the public. Anggara (2014) and Kholisoh, Yuliawati, Suci and Suharman (2019), stated that public trust is the dominant factor affecting public policies. Low public trust leads to the public having low supporting capacity, being sceptic and a priori about policies. Furthermore, there is no compliance as expected.

This is strengthened by Sidauruk (2013) in his study on the role of communication in implementing internet service policy at a sub-district level. The study noted that a lack of communication role made the implementation of internet service program unable to reach maximum results. Prasetya and Fauziah (2017) shared the view in their study on the impact of economic socialisation on the relocation of street vendors. The result of the study shows that without good socialisation, the result of relocation will not be good accordingly.

Meanwhile, a public policy that is conveyed properly with good mentorship will result in expected relocation as concluded by Mayasari, Kusuma and Syahrani (2014) in their study on the relocation of residents living along the banks of River Karangmumus in East Kalimantan. The research conducted by Lestari, Kertamukti and Ruliana (2019) with Lestari, Ritonga, Ruliana and Barus (2020) also stated that heart-to-heart communication or communication for peace produces effective local wisdom in settling land conflict in North Sumatra.

Regional governments outside Jakarta have also carried out demolition to implement their regional policies. However, the relocation and demolition process did not cause a conflict and misunderstanding between the regional governments and their residents owing to good communication to convey public policies.

On the contrary, the implementation of public policy related to the relocation of residential areas in Jakarta has always ended in chaos. In such perspective, this study is conducted by analysing the messages of Ahok's political communication related to his policy of normalising River Ciliwung, which in its implementation caused communication crisis due to residents' refusal of the policy.

\section{LITERATURE REVIEW}

Political communication is part of daily life. To carry out daily activities, nobody does not communicate with other people. The communication very often involves political themes consumed from various sources of information. Denton and Woodward in McNair (2017), provide one definition of political communication as public discussion about the allocation of public resources (revenues), official authority (who is given the power to make legal, legislative and executive decision), and official sanctions (what the state rewards or punishes). 
Raja Nurafiqah, Noor Sulastry, Mohd Azizuddin and Haslina (2018) state, political satire is also one of the forms of political communication. Denton and Woodward in McNair (2017) opine, the crucial factor that makes communication "political" is not the source of a message but its content and purpose. The definition has its certain limitations; first, limitation on verbal and written political rhetoric only; and second, limitation on state executors.

The second limitation is influenced by Max Weber's thought related to state executors as human community that has successfully monopolised the legitimate use of physical force within a given territory (Surbakti, 1992). For Weber, politics is rivalry to distribute power or rivalry to influence the distribution of power among states or among groups within a state. In this approach, a state is seen as an institution that has interests which are different from various interests of those competing or conflicting in the community. This view is also called statist perspective (Surbakti, 1992).

The scholars' view obviously mentions activities in political communication, covering: rivalry, attempt to influence, activities related to power, government and government policies (those governing and those governed), political discussion to resolve a conflict or problem. All the activities occur in a political system. Dahl in Arifin (2011) formulates political system as a pattern of human relations covering; control, influence, and power or authority.

Political communication is an ubiquitous phenomenon in a political system. The communication between Ahok and the public to implement the policy of relocating residents living along the banks of River Ciliwung in Kampung Pulo is political communication because it happened through political process in a political system involving rivalry and conflict, attempt to influence, activity related to power, government and policy, settled through political talk and symbolic communication act.

\section{Political Talks}

Politics and communication are a process. Like communication, politics involves talk. According to Nimmo (1978), the talk is not limited to the words uttered, but is more exclusive talk about various ways to exchange symbols, such as words written and uttered, pictures, motion, body language, behaviour and clothes. Nimmo (1978) quoted a statement by Bell that the talk that influences other people, by definition, has carried political elements.

According to Bell in Nimmo (1978), there are three types of talk that have political interests, namely power talk, influence talk, and authority talk. Power talk is the way of influencing other people by threat or promise. It may come in the form of, "If you do X, I will do Y".

Influence talk occurs without sanctions. It may come in the form of: "If you do X, you will do (feel, experience) $Y^{\prime \prime}$. Promise, threat, bribe, and extortion serve as a means of communication transaction to control power. Authority talk is giving an order without conditions. It may come in the form of, "Do X" or "Don't do X". Authority talk is instructive form rather than contingent form, which is the typical characteristic of power and influence.

According to Susanto (2013), a politician is basically a professional communicator and activist as political communicator. Politician must have the capacity to conduct political communication, thereby having the chance and capacity to become a leader capable of organising messages to the general public properly. Political communicator cannot keep away from the capacity to organise messages to the general public that demand state democratisation, welfare and justice.

Political talk is a symbolic activity. Through symbols, people can exchange images or meanings. Hence, according to Nimmo (1978), the primary elements of talk are symbol, 
symbolised matters, and interpretation making symbol meaningful. In political talk, words are a political symbol and therefore, any exchange of words indicates the struggles of various social interests which sometimes have the ultimate goal of obtaining materials and upgrading or downgrading status.

At the end, according to Nimmo (1978), the instruments create and strengthen confidence, feeling and expectation that several people have the right to govern because they are more suited than the others. The linguistic forms build relations between talk and status. They can downgrade status in such a way that it will be worthless and degraded, but they can also upgrade status such as the following words: stewardess to flight attendant, nursemaid to child monitor, and charwoman to houseworker.

\section{Conflict and Conflict Management}

Conflict is a condition caused by the force of those conflicting (Luthans, 2006). According to Gunawan and Rante (2011), conflict occurs due to a process which happens in both sides, each of which is influenced negatively, leading to a conflict between both sides. Basically, politics always contains conflict and competition of interests.

A conflict usually starts from controversy that arises in various political events. The controversy is preceded by abstract and common things which later develop into a conflict (Hidayat, 2009). Political conflict is a collective activity carried out by community members to oppose political decision, public policy and its implementation as well as the attitude of the rulers along with all regulations, structures and procedures governing relations among political participants (Surbakti, 1992).

Minnery (1985) defines conflict management as an iterative rational process in which the process occurs continuously and continues to improve until an ideal and representative model is achieved.

According to Ross (1993), conflict management is a step taken by agents or third parties to direct a dispute towards achieving certain results that may or may not produce tranquility, positive thing, creativity, agreement or aggressiveness. This is in line with the results of a research conducted by Wilson and Ibrahim (2018) that the Philippines has proposed various options to create peace in Sulu, East Borneo in which the only way to rescue lives is agreeing to ceasefire and producing win-win solution.

According to Baskerville (1993), there are six types of conflict management, namely Avoiding: In general, individuals or organisations tend to avoid conflict. Various sensitive things that potentially cause a conflict should be avoided as far as possible; Accommodating: Collecting various views from many parties involved in a conflict; Compromising: Paying attention to views and interests of all parties; Competing: Settling a conflict by directing the conflicting parties to compete with one another and win their respective interests. One of the parties will lose or give in to the other party; Collaborating: Settling a conflict by establishing cooperation to achieve satisfactory results because all parties synergise to solve the problem by paying attention to the interests of all parties; and Conglomeration: Settling a conflict by combining the five types of conflict management. These types of conflict management need a lot of energy, time and thought to settle a conflict. 


\section{Coodinated Management of Meaning Theory}

Coordinated Management of Meaning Theory was introduced by West and Turner (2013). This theory sees that there are so many possible meanings of object, event or occurrence. Any act of communication has purpose. The underlying basis of Coordinated Management of Meaning Theory is that the communication of each individual tries to manage and coordinate the various meanings.

There are six elements of meaning according to West and Turner (2013), namely Content: Serving as an initial step, where raw data is converted into meaning; Speech act: Referring to an act taken by speaking including praising, insulting, promising, threatening, stating and asking; Episode: Referring to routine communication, having a clear start, middle and end; Relationship: Being interpreted as an agreement contract and understanding between two people where there is demand in attitude; Life Scripts: Referring to groups of past or present episode that create a meaning system managed together with other people; and Cultural Pattern: Referring to a picture of world and how an individual has relations with the matter.

By using this theory as a "analysis knife", the meaning of the message of policy conveyed by Ahok to residents affected by the relocation project can be understood. In addition, the meaning of message received by the residents affected by relocation in Kampung Pulo from the message of the policy conveyed by Ahok can also be understood.

\section{Speech Act Theory}

Speech act is used not only to point at something, but also to do something. This means that communication uses not only language, but action as well. The speech act theory is rooted from the idea of Littlejohn and Foss (2009) in 1953, who disclosed linguistic philosophy theory that the linguistic meaning cannot be found in words and grammar, but in how people use language to accomplish certain objectives within the situation in which they act. Wittgenstein affirmed that utterances do more than reflect a designated meaning, but they are forms of action designed to get thing done.

According to Littlejohn and Foss (2009), following this idea Austin stated in the classical text How to Do Things with Words, that making an utterance is a speech act, or an action performed through language/way of speaking/speech. Austin distinguished three aspects related to speech, namely locution, the act of making speech sounds or uttering something. However, such locutions rarely stand by themselves.

They also serve to express an intention beyond the mere utterance of speech; illocution, a certain thing meant or desired to be accomplished from a speech act. Illocution elicits an understanding in others of what one means to accomplish; perlocution, referring to the effect caused by speech act produced. If the listener understands what kind of response is required, the statement has perlocutionary force as well as illocutionary force. In perlocution, the speaker taking a certain act expects the listener to not only understand, but also act based on the understanding.

\section{Implementation of Public Policy}

This research involves a concept of public policy as a field of study related to political communication. The definition of policy is needed to enable us to keep the clarity of our thoughts in further discussion. This is asserted by Budiardjo (2003), that policy is one of concepts in political sciences. Policy is a series of decisions taken by political actors (individuals or groups) that have power or authority to decide the goal and how to achieve it. 
Ramdhani and Ramdhani (2017) stated that public policy is a series of decisions related to public interests made by the government in a conscious, well-guided and measurable way by involving parties having interests in certain fields and directed towards achieving certain goals. Dye, as quoted by Winarno (2002), defined public policy as what is done by the government, how to do it, why it needs to be done and what difference is made. Dye's view of public policy has wider perspective, namely whatever governments choose to do or not to do.

A policy that has been formulated will be meaningless if it is not implemented. Udoji in Wahab (2008) stated the implementation of policy is something important. Udoji stated, without being implemented, the policy that has been formulated will be a mere dream or a good plan kept neatly in the archives.

According to Dunsire in Wahab (2008), there is always an implementation gap when the policy is done. This means that there is always difference between what is expected or planned by the policy maker and the reality achieved from the implementation of the policy. Whether the difference will be large or small depends on the capacity of the organisation or actor to implement the policy to achieve the given goals (implementation capacity). Hence, transparent policy is needed to encourage public participation.

\section{Resettlement}

Relocation referred to in this research is the act of removing the residents of Kampung Pulo from the banks of River Ciliwung which are frequently flooded, to West Jatinegara flats. The term "relocation" refers to several previous researches conducted by Mayasari et al. (2014), Rahman and Nurhamlin (2014) and Purnomo (2016) .

Meanwhile, Arnall, Thomas, Twyman and Liverman (2013) and Hernández et al. (2016) use more specific term, namely resettlement to refer to the relocation of human settlement from one place to a new place which is more secure. Based on the above explanation, the use of the term relocation also refers to the definition of resettlement.

Oliver-Smith (1991) opined the negative consequences of involuntary displacements extend far beyond the loss of land rights. He mentions the impact of resettlement on the affected people are: the loss of physical and non-physical assets, including homes, communities, productive land, income-earning assets and sources, subsistence, resources, cultural sites, social structures, networks and ties, cultural identity and mutual health mechanism; the loss of ties between people and their environment in individual and collective identity formation within interpersonal, community and intercultural relations; the fragmentation of community and loss of social and political forces; the disruption of productive activities due to the loss of resources such as land, business sites, and jobs, while such opportunities are not available at the site.

\section{METHODOLOGY}

This research uses a qualitative approach with constructivist paradigm developed by Denzin and Lincoln (2011). The research method used is case study with a single case. Smith in Denzin and Lincoln (2011) mention, case is a "bounded system" as asserted by Denscombe in Pambayun (2018) that case study must have clear distinct boundaries.

The researcher analysed the message of Governor Ahok's political communication related to the implementation of policy to normalise River Ciliwung, namely the relocation of residential area along the basin area of River Ciliwung. This research focuses on the process 
in which the residents of Kampung Pulo received the message of the policy. The research subject is the institution implementing the policy and the residents affected by the policy. The research subject refers to the view of Arinkunto (2002) that research subject is a source of data from whom information is sought in accordance with the issue researched.

\section{RESULT AND DISCUSSION}

In the relocation of Kampung Pulo residents, political actors vied for the same resources. The political actors were Ahok and Kampung Pulo residents. Competition between the two sides to struggle for their respective interests can be seen from difference of opinion, debate and even physical clash. In Ahok's side, there was an interest to achieve values in the form of residents' compliance with the policy of normalizing and controlling the banks of River Ciliwung claimed to be state land. On the other hand, the residents of Kampung Pulo affected by the project make every effort to defend what they have controlled so far, namely land and buildings.

The conflict of interests between Ahok and the residents of Kampung Pulo involves political language and talk. Nimmo (1978) describe it as a talk about politics; in which the two political actors settle their dispute by formulating a word vocabulary about assumption, meaning, expectation and joint commitment.

The use of "political language" in political communication was also conveyed by Doris Graber in McNair (2017). This term shows that political communication covers not only rhetoric, but also symbolic communication act and paralinguistic signal such as body language and political act such as boycott and protest.

Through the exchange of symbols, namely the use of political language and talk, the message of policy in the form of Regional Regulation (2016a) No. 1 of 2012 concerning Provincial Spatial Planning 2030, and Perda (2014b) No. 1 of 2014 concerning detailed spatial planning, was conveyed to the public. In implementing the policy of relocating the residents of Kampung Pulo, there are three types of communication messages done by Ahok, namely socialisation of policy, written warning and deployment of joint security apparatuses. The three types of communication messages cover verbal and non-verbal symbols in political communication.

The socialisation of policy related to the Regional Regulations (Perda) is done through several meetings. In addition, other verbal symbols used by Ahok are Gubernatorial Regulation, Gubernatorial Decision, and Written Warnings I, II, III that warn the residents affected by the project to move from Kampung Pulo immediately. The symbols serve as a symbol of authority talk.

As a symbol of authority talk, the regulations issued by Ahok and written warnings issued by the Public Order Agency, according to Nimmo (1978), symbolise mutual understanding which is worthy of being followed; have the same authority meaning and value as constitution, law, treaty and so on.

The socialisation efforts made by mayor, sub-district head and urban village head ended in deadlock because they were seen by the residents as a one-way communication made by Ahok. The picture confirms the view of Nimmo (1978) as authority talk. Authority talk reflects the form of order rather than contingent form, which is the typical characteristic of power and influence (Nimmo, 1978). In fact, the residents expected a meeting and wanted Ahok to hear their objection to reach a decision for the common good. 
The other symbol used by Ahok was a show of power by deploying 2,150 joint security apparatuses from the Public Order Agency, police and military. In the context of political communication, the model of communication is known as communication between "the governing and the governed". The message that Ahok wanted to convey was authority message and power message.

The view of Bell in Nimmo (1978), political talk including power talk is done to influence other people by using threat or promise. One of the statements of Ahok is "If two thousand people are opposed to me and endanger 10 million people, I (will) kill (them) in front of you". The statement of Ahok appears to use language of power as stated by Nimmo (1978). The typical model is, "If you do X, I will do Y". The key to the authority talk is, 'I' (Ahok) that has enough capacity to fulfil promise and realise his threat.

In addition to the exchange and meaning of symbols between Ahok and the residents of Kampung Pulo, there is also the use of several dictions which according to Nimmo (1978) have purposes: first, political talk to achieve material; second, political talk to upgrade or downgrade status.

The result of this research shows the use of words or phrases as follows: 'our brothers who have not had luck', or 'those who are less fortunate'. These terms were often used by Ahok and the ranks and files of the Provincial Government of Jakarta to refer to the residents of Kampung Pulo. The use of the terms in political talk constitutes euphemism to mention terms considered firmly offensive, or terms giving the impression of attacking or cornering somebody. The use of euphemism shows the act of giving meaning to oneself (Ahok) that he was superior to the group of people he mentioned, the residents of Kampung Pulo.

According to Nimmo (1978), political leaders often use euphemisms, jargon, and convoluted words to blur the real condition. In the relocation of the residents of Kampung Pulo, Ahok used euphemism to treat the residents rejecting the relocation. This is contrary to the fact. The residents felt intimidated and scared verbally, given the written warning to move immediately and Public Security Agency personnel coming in and out of the residential area. The situation culminated when joint security personnel clashed with the residents.

In an effort to achieve material through the use of political language, Ahok also used metaphor language. This language, according to Nimmo (1978), is used to convince the public and residents affected by a policy that the policy benefits them, while at the same time concealing information about the adverse impact of the policy.

It is mentioned in the statement of Ahok to the public that the residents of Kampung Pulo who were relocated need not pay rent, but daily maintenance fees. This statement gives an impression that the policy benefited the residents of Kampung Pulo. In fact, a tenant of rented flat, said he stayed at the flat free of charge only for three months, and thereafter he paid a monthly rent of $\mathrm{Rp} 300,000$.

Ahok also used the terms 'illegal residents', 'tenants of state land', to refer to the identity of the residents of Kampung Pulo. He dubbed them 'illegal residents', 'tenants of state land', because they could only show proof of ownership in the form of draft new ownership (substitute for verponding). The notion clarifies the meaning of Kampung Pulo residents' identity in the thoughts of Ahok and the collective thoughts of the ranks and files of the Provincial Government of Jakarta involved in the relocation process. This reminds us of the relations between meaning and act as stated by Blumer (1969, p.11): "individuals behave towards objects and others based on the meaning of the objects for them." 
Ahok also dubbed the residents 'land embezzlers', and 'the poor'. The word 'poor' in the Large Dictionary of Indonesian Language means having no property; lacking means, having very low income. The dubbing suggests that Ahok discriminated against a group of people that lack economic means.

The term 'land embezzlers' is derived from the verb 'embezzle'. The word 'embezzle', in the Large Dictionary of Indonesia Language means, among others, taking something without the knowledge of the owner. By using the word, Ahok accused Kampung Pulo residents of being a group of people taking land without right. The statement of Ahok that linked the term "land embezzlers" constructed negative meaning in the heart of the public to the owner of the symbol.

According to Nimmo (1978), the use of such form of language is called labeling, namely applying offensive words to individuals, groups, or activities. Labeling is the opposite explanation of euphemism. The labeling of individuals, groups or activities is done to show that something is worthless and contemptible.

In addition to political talk, political communication between Ahok and Kampung Pulo residents is also closely related to the consistency of meaning and act. Communicators, according to Littlejohn and Foss (2009), do two things in each meeting. They interpret or consider meaning and take action -- two functions that are closely related to one another; Meaning leads to action, and action forms meaning. Communicators must coordinate meaning and their actions while they interact all the time.

Only by using Coordinated Management of Meaning Theory, can we know how Ahok and Kampung Pulo residents, controlled meaning and their action to several types of pattern acceptable to them. What happened to the communication between Ahok and Kampung Pulo residents is communication pattern in mediation. In this regard, mediation is done because both actors have different interests. To that end, this study uses four contexts of Coordinated Management of Meaning theory, namely: certain episode, relationship between parties, identity of speaker, and culture of organization or society from which he/she comes.

Episode (West \& Turner, 2013) is a sequence of speech acts by uniting the beginning and ending of a story. This refers to routine communication has a clear beginning, middle and ending. In the relocation of Kampung Pulo residents, communication episode started when Regional Regulation (Jakarta, 2014b) No.1/2012 concerning Regional Spatial Planning of 2030, and Regional Regulation No. 1/2014 concerning Detailed Spatial Planning (RDTR) were issued. The regulations gave birth to derivative policies in the form of Gubernatorial Regulation No. 163/2012, and Gubernatorial Decision (Jakarta, 2014a) No. 2181/2014 stipulating that 518 homes must be demolished due to the normalisation project in Kampung Pulo.

Interaction began during the socialisation of the project in April 2013. The then East Jakarta Mayor disclosed compensation for residents affected by the project in accordance with Gubernatorial Regulation No.190/2014 issued and signed by Ahok concerning Guide to Granting Compensation to Cultivators of State Land. The residents gave a positive response to the socialisation and threw their weight behind the normalisation policy. The residents interpreted the policy that they would receive compensation in accordance with the regulation. However, two years later, Ahok revoked Gubernatorial Regulation (Jakarta, 2014a) No. 190/2014 and issued Gubernatorial Regulation (Jakarta, 2016b) No. 144/2016 stating that there was no compensation. The amendment to this regulation was socialised on June 5 , 2015. 
In this episode, Ahok had different interpretation of Kampung Pulo residents' identity. In Ahok's view, Kampung Pulo residents are illegal residents because they built settlement on state land without permission, whereas the residents saw themselves as legal residents, evidenced by identity cards (population identity card), tax payment receipts, electricity and water bills.

In the context of relationship, since the socialisation began on June 5, 2015, the relations between Ahok and Kampung Pulo residents had been disrupted. The residents walked out of the socialisation and set up a Free Ciliwung organisation, accompanied by local public figures. The reaction was speech act of the residents due to Ahok's inconsistent attitude. Governor Ahok's inconsistent attitude had impaired his relations with Kampung Pulo residents. The next speech act of the residents was holding a peaceful rally on June 10, 2015; marching from Kampung Pulo to Jatinegara rented flat by unfurling a banner containing several demands.

The peaceful rally was responded by Ahok by issuing a written warning. The residents interpreted Ahok's speech act to issue the written warning as a form of intimidation act. The written warning ordered the residents to empty their homes immediately within the given time. In addition, Ahok did not give the residents a chance to discuss compensation.

The next episode was that representatives of Kampung Pulo residents held meetings with Ahok on July 24, 2015 and August 4, 2015. In the July 24, 2015 meeting, both sides reached several joint agreements. One of them was that the residents did not reject normalisation and even did not object to being relocated, provided the new settlement was based on the concept of "community-based flat kampong" in order to maintain their diverse cultures and social ties. The new settlement is expected not to deprive the residents of their daily sources of livelihood.

In August 4, 2015 meeting, the talk ended in deadlock. Ahok stuck to data provided by Kampung Melayu urban village head that $80 \%$ of land ownership in Kampung Pulo was based on sale and purchase agreements for state land. Ahok maintained his view to give a meaning to the identity of Kampung Pulo residents as illegal residents.

The relations became tense again, with representatives of the residents rejecting to sign any agreement with Ahok. They opined Ahok's offer would only solve the issue of settlement, but he did not consider the impact of the relocation, including the loss of income sources or other sources due to the disruption of productive activities and social relations among the residents.

In the context of culture, individuals who come from different cultures will not interpret a message in the same way. They showed this attitude while responding to settlement offer from Ahok. For Ahok, who comes from middle-class culture, a house is a symbol of place to gather with family after working throughout the day. For Kampung Pulo residents who are accustomed to living in a densely-populated settlement, homes also serve as a production site. Losing homes amounts to losing sources of livelihood. Therefore, they struggled hard to defend the sources of livelihood even though there was physical clash with security personnel. 
Following is the hierarchical-serpentine model, in Griffin (2006), between Ahok and residents affected by the River Ciliwung normalisation project in Kampung Pulo (Diagram 1).

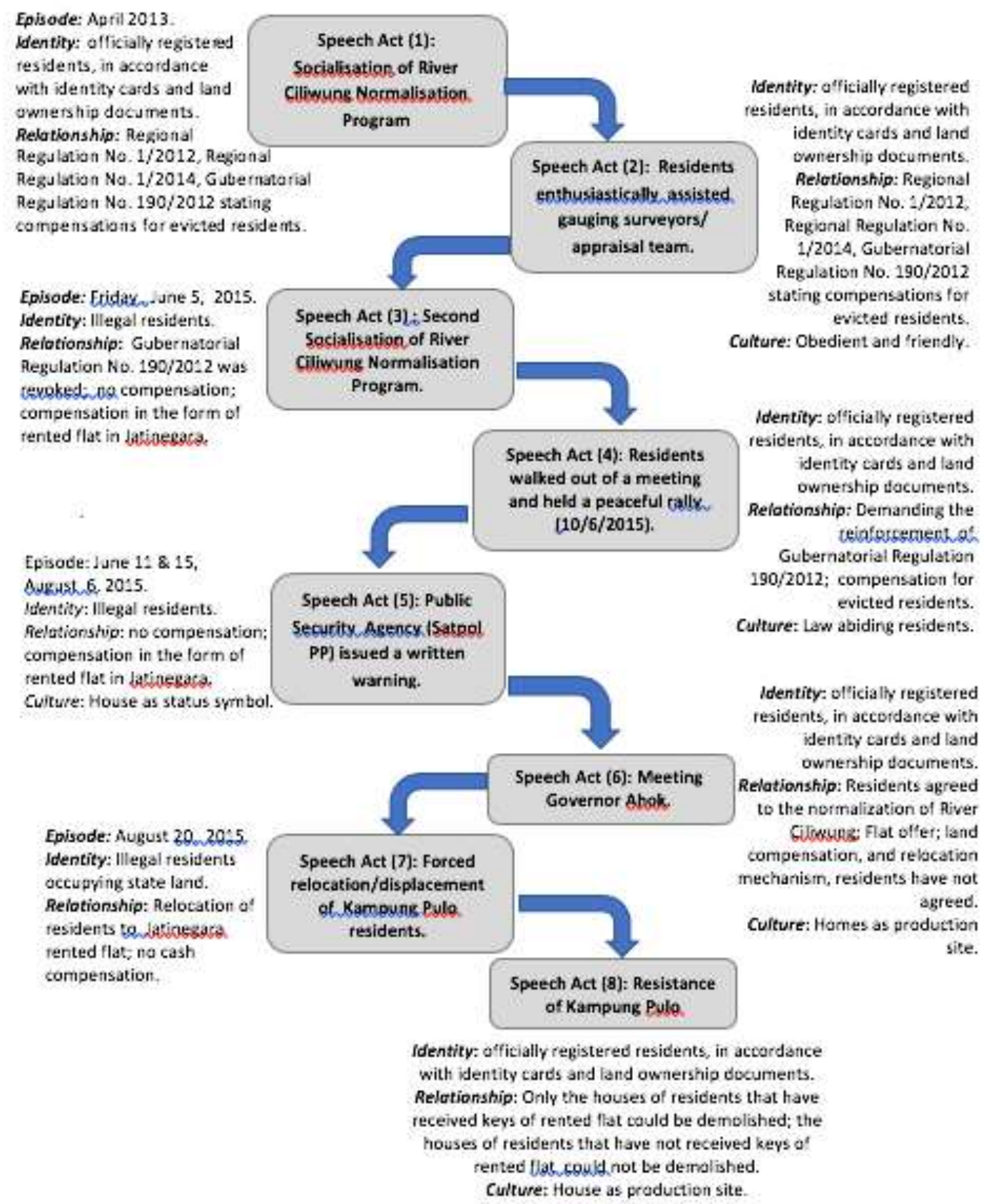

Diagram 1: Hierarchical-Serpentine Model Political Communication between the Governor Ahok and residents of Kampung Pulo

Diagram 1 shows speech act (1), Ahok shaped in action (perlocution), namely socialisation of program. This action was formed by a number of locutions occurring in the process of communication between Ahok and Kampung Pulo residents in several contexts. For instance, in the context of relationship, Ahok offered compensation in accordance with Gubernatorial Regulation No. 190/2014. In this stage, Ahok saw the identity of residents as legal residents. The residents replied it with speech act (2), in which they enthusiastically assisted a gauging surveyor team. In this stage, the meaning and action of the residents and Ahok are considered rational for both sides. In the context of identity, the residents are 
recognised as legal residents, and in the context of relationship, Ahok was ready to provide compensation in accordance with Gubernatorial Regulation No. 190/2014. In the context of culture, the residents showed enthusiasm to provide assistance as obedient and friendly residents.

Speech act (3), Ahok conducted the second socialisation of normalisation program on June 5,2015 . In this stage, the contexts forming Ahok's speech act had changed. The identity of the residents that was previously considered legal, was later considered illegal in the communication, and the rights of the residents that had previously been calculated and gauged (in speech act $r 2$ ) were considered by Ahok to be on state land. The assumption of Ahok changed the context of relationship between the two sides, which was previously good and harmonious turned into hostility. In addition, Ahok also stated that there would not be compensation, except rented flat in West Jatinegara.

In retaliation, the residents took speech act (4) by walking out of the meeting. The residents later held a meeting in Kampung Pulo which brought together some 300 representatives of the residents. The meeting agreed to demand Ahok to realise the previous agreement that there would be compensation as contained in Gubernatorial Regulation No. 190/2014 concerning Guide to Providing Compensation to State Land Cultivators. To voice their demand Kampung Pulo residents staged a peaceful rally on June 10, 2015. In this stage, the contexts forming the speech act of the residents did not change. The peaceful rally reflects the context of the residents' culture as law-abiding community.

Ahok responded to it with speech act (5), namely, by issuing a written warning to press the residents to move immediately. In this stage, the contexts forming speech act remain the same as speech act (3), whereas compensation in the form of rented flat reflects the context of Ahok's culture which sees house as a symbol of status. The residents who felt intimidated responded to it by holding audience with Ahok, as a form of speech act (6). In the context of relationship, the residents supported the normalisation project; but when it comes to rented flat both sides differ in the context of culture, in which the residents see house as a production site. This means that for Kampung Pulo residents, house serves as a place to live and run business activities.

The peak is speech act (7), Ahok carried out the forced relocation of Kampung Pulo residents who insisted on refusing to follow his will on August 20, 2015. The residents responded to the action by making resistance as a form of speech act (8). The uncoordinated management of meaning in speech acts (3), (4), and (5), could have been saved in the phase of speech act (6), but at the end both sides were confined to their own meaning of the other. Based on Diagram 1, it is understandable that the episode of communication from beginning to end is related to the meaning of identity, influenced by culture, thereby disrupting relationship between actors.

Speech acts 1 to 7 are presented in Table 1 depicting the positions of the two political actors from beginning to end before the clash broke out on August 20, 2015. 
Table 1: The Coordination of Meaning between Ahok and Kampung Pulo Residents

\begin{tabular}{|c|c|c|}
\hline Contexts & Meaning by Gubernur Ahok & Meaning by Residents \\
\hline Identity of residents & $\begin{array}{l}\text { Illegal residents, state land occupants, } \\
\text { land embezzlers }\end{array}$ & $\begin{array}{l}\text { Officially registered residents in } \\
\text { accordance with identity cards, who } \\
\text { always meet obligations (paying tax, } \\
\text { electricity, water, etc. bills). }\end{array}$ \\
\hline Relationship & $\begin{array}{l}\text { No compensation. No legal basis dince } \\
\text { Gubernatorial Regulation No. } \\
\text { 190/2014 has been revoked }\end{array}$ & $\begin{array}{l}\text { Meaning by residents, there was } \\
\text { compensation in accordance with } \\
\text { the initial socialisation, referring to } \\
\text { Regional Regulation No.1 / 2012, }\end{array}$ \\
\hline & & $\begin{array}{l}\text { Gubernatorial Regulation No. } \\
\text { 190/2014. }\end{array}$ \\
\hline $\begin{array}{l}\text { Context, Aspect of } \\
\text { cultural value in giving } \\
\text { meaning to rented flat }\end{array}$ & $\begin{array}{l}\text { Rented flat used as compensation is } \\
\text { categorized as luxury. Rented flat } \\
\text { becomes a symbol of status }\end{array}$ & $\begin{array}{l}\text { House must serve as a } \\
\text { business/production site in the } \\
\text { same way as old homes in } \\
\text { Kampung Pulo. }\end{array}$ \\
\hline $\begin{array}{l}\text { Episode - Ownership } \\
\text { documents }\end{array}$ & $\begin{array}{l}\text { Without land ownership certificate, } \\
\text { land fully belongs to the state }\end{array}$ & $\begin{array}{l}\text { Land ownership document is } \\
\text { Verponding (land and building tax } \\
\text { return form) }\end{array}$ \\
\hline $\begin{array}{l}\text { Episode - Socialisation of } \\
\text { compensation }\end{array}$ & $\begin{array}{l}\text { No compensation since there is no } \\
\text { legal basis }\end{array}$ & $\begin{array}{l}\text { Compensation was offered at the } \\
\text { beginning but was later cancelled } \\
\text { without clear basis. }\end{array}$ \\
\hline
\end{tabular}

Through mediation process, the two communicators were expected to produce patterns of speech act to achieve solution. But the fact can be seen at Table 1. Ahok was confined to his meaning of the identity of Kampung Pulo residents as illegal residents. However, the residents showed their evidence to challenge the claim. The offer of rented flat in West Jatinegara, according to Ahok, is a luxury which is beyond the decent home of Kampung Pulo residents. For Kampung Pulo residents who are accustomed to living and interacting in a densely-populated area, the luxury will be meaningless if they cannot carry out business activities because they see house as a source of livelihood. The difference of the two communicators' culture caused difficulties to them to find a common solution.

The worsening relationship between the two communicators shows that their interaction was not coordinated properly. The lack of coordination was found when the two communicators could not connect their actions in a rational way according to their counterpart. Each of them believed that their action is the most reasonable one, while interpreting the action of the other party as irrational.

\section{CONCLUSION}

Communication between Governor Ahok and Kampung Pulo residents occurred in the perspective of a conflict over the same resources by involving political language and talk. Ahok used the models of political language such as euphemism, metaphor and labeling. As the nature of communication which is a reciprocal and sustainable process of sharing meanings and responses, Ahok and Kampung Pulo residents regulated meanings and actions in several types of patterns which are reasonable for them.

Ahok and Kapung Pulo residents mutually responded to a number of speech acts formed through the contexts of episode, identity, relationship, and culture. At the end, both sides were confined to their own meaning of the other party. The residents insisted on demanding fair compensation because they feel they are legal residents. On the other hand, 
Ahok was confined to the meaning of Kampung Pulo residents' identity as illegal residents and thus, there was no other compensation than rented flat. The dispute culminated when Ahok resorted to the forced use of instrument by deploying joint security personnel from the Public Order Agency, the National Police and the Indonesian Military in accordance with his authority.

The findings of this research suggest that in implementing public policies, the Provincial Government of Jakarta should take into account the clarity and consistency of information about the implementation of policies at each level of policy-executing unit. In addition, the relocation of Kampung Pulo residents should involve the affected residents since the relocation is closely related to their livelihood including material resources and cultural resources. Moreover, they rely on their life as individual and community in their residential area.

BIODATA

Nur Kholisoh is an associate professor of the Faculty of Communication Sciences at Universitas Mercu Buana in Jakarta, Indonesia. Email: nur.kholisoh@mercubuana.ac.id

Yuventus Newin Bylmoreno is a lecturer of the Faculty of Communication Sciences at Universitas Mercu Buana in Jakarta, Indonesia. Email: bylmoreno74@yahoo.com 


\section{REFERENCES}

Ahmadi, D., Rachmiatie, A., \& Nursyawal. (2019). Public participation model for public information disclosure. Jurnal Komunikasi: Malaysian Journal of Communication, 35(4), 305-321. https://doi.org/10.17576/JKMJC-2019-3504-19

Anggara, S. (2014). Kebijakan publik. Jakarta: Pustaka Setia.

Arifin, A. (2011). Komunikasi politik: Filsafat, paradigma, teori, tujuan, strategi, dan komunikasi politik Indonesia. Yogyakarta: Graha IImu.

Arinkunto, S. (2002). Prosedur penelitian suatu pendekatan praktek. Jakarta: PT Rineka Cipta.

Arnall, A., Thomas, D. S. G., Twyman, C., \& Liverman, D. (2013). Flooding, resettlement, and change in livelihoods: Evidence from rural Mozambique. Disasters, 37(3), 468-488.

Baskerville, D. M. (1993). How do you manage conflict?. Black Enterprise, 23(10), 62-66.

BBC News Indonesia. (2016, April 11). Penggusuran pasar ikan Luar Batang sempat diwarnai kericuhan.

Blumer, H. (1969). Symbolic interactionism: Perspective and method. NJ: Prentice-Hall.

Budiardjo, M. (2003). Dasar-dasar ilmu politik. Jakarta: Gramedia pustaka utama.

Denzin, N. K., \& Lincoln, Y. S. (2011). The Sage handbook of qualitative research. Thousand Oaks: Sage.

Griffin, E. M. (2006). A first look at communication theory. New York: McGraw-hill.

Gunawan, K., \& Rante, Y. (2011). Manajemen konflik atasi dampak masyarakat multikultural di Indonesia. Jurnal Mitra Ekonomi Dan Manajemen Bisnis, 2(2), 212-224.

Hernández, M., Cardona-Muñoz, L., Celis Zapata, L., Iglesias-Acosta, J., Meléndez-Labrador, S., Ospina Guzmán, M., ... others. (2016). Community participation and communication processes in the implementation of programs of resettlement of families within the context of urban development in the city of Barranquilla (Colombia). Revista Salud Uninorte, 32(3), 528-543.

Hidayat, I. (2009). Teori-teori politik. Yogyakarta: Setara Press.

Idris, I. K. (2018). Government social media in Indonesia: Just another information dissemination tool. Jurnal Komunikasi: Malaysian Journal of Communication, 34(4).

Jakarta, D. (2014a). Peraturan gubernur No.190/2014 tentang pedoman pemberian santunan kepada penggarap tanah negara [Gubernatorial regulation No.190/2014 concerning guide to granting compensation to state land cultivators]. Indonesia: DKI Jakarta. Retrieved from https://jdih.jakarta.go.id/himpunan/produkhukum_detail/3460

Jakarta, D. (2014b). Perda no 1 tahun 2014: Rencana detail tata ruang dan peraturan zonasi DKI Jakarta [Regional regulation no. 1/2014 concerning detailed spatial planning (RDTR)]. Indonesia: DKI Jakarta. Retrieved from https://pelayanan.jakarta.go.id/download/regulasi/peraturan-daerah-nomor-1tahun-2014-tentang-rencana-detail-tata-ruang-dan-peraturan-zonasi.pdf

Jakarta, D. (2016a). Peraturan daerah (Perda) nomor 1 tahun 2012 tentang rencana tata ruang wilayah tahun 2030 [Regional regulation no. 1/2012 concerning regional spatial planning of 2030]. Indonesia: DKI Jakarta. Retrieved from http://pelayanan.jakarta.go.id/download/regulasi/peraturan-daerah-nomor-1tahun-2012-tentang-rencana-tata-ruang-wilayah-2030.pdf

Jakarta, D. (2016b). Peraturan gubernur provinsi DKI Jakarta nomor 144 tahun 2016 tentang pedoman pemberian santunan kepada penggarap tanah negara [Regulation of the governor of the provincial capital of Jakarta No. 144/2016 concerning guide to granting compensation to state]. Indonesia: DKI Jakarta. Retrieved from https://jdih.jakarta.go.id/himpunan/produk_download/5790 
Januardy, A. F., \& Demadevina, N. (2016). Atas nama pembangunan: Laporan Penggusuran Paksa di Wilayah DKI Jakarta Tahun 2015 [In the Name of Development: A Report on Forced Evictions in the Jakarta Province Administrative Area in 2015]. Jakarta: Lembaga Bantuan Hukum Jakarta. Retrieved from https://www.bantuanhukum.or.id/web/wp-content/uploads/2016/02/LaporanPenggusuran-2015_LBHJ_web.pdf

Kholisoh, N., Yuliawati, E., Suci, N. R., \& Suharman, T. (2019). The influence of political messages in new media to political awareness and its impact on the political participation of millennial generation. Jurnal Komunikasi Ikatan Sarjana Komunikasi Indonesia, 4(2), 128-139.

Lestari, P., Kertamukti, R., \& Ruliana, P. (2019). Use of local wisdom (purpusage) through heart-to-heart communication in settling of social conflicts in Karo, North Sumatra Indonesia. Jurnal Komunikasi: Malaysian Journal of Communication, 35(3).

Lestari, P., Ritonga, R., Ruliana, P., \& Barus, C. C. B. (2020). Disaster communication uses field training exercise simulation as an important aspect of disaster risk reduction. Jurnal Komunikasi: Malaysian Journal of Communication, 36(1).

Littlejohn, S. W., \& Foss, K. A. (2009). Teori komunikasi. Jakarta: Salemba Humanika.

Luthans, F. (2006). Perilaku organisasi (Edisi 10). Yogyakarta: Andi.

Mayasari, A. D., Kusuma, A. R., \& Syahrani. (2014). Persepsi masyarakat terhadap kebijakan relokasi penduduk Bantaran Sungai Karangmumus Samarinda Kalimantan Timur (Studi kasus: Kebijakan relokasi penduduk Bantaran Sungai Karangmumus). Ejournal Administrative Reform, 2(4), 2422-2434.

McNair, B. (2017). An introduction to political communication. Oxon: Routledge.

Minnery, J. R. (1985). Conflict management in urban planning. Aldershot: Gower.

Nimmo, D. D. (1978). Political communication and public opinion in America. Santa Monica, California: Goodyear Publishing Company.

Oliver-Smith, A. (1991). Successes and failures in post-disaster resettlement. Disasters, 15(1), $12-23$.

Pambayun, E. L. (2018). One stop qualitative research methodology in communication. Yogyakarta: Lentera IImu Cendekia.

Prasetya, M. A., \& Fauziah, L. (2017). Dampak sosial ekonomi relokasi pedagang kaki lima di kecamatan Buduran Kabupaten Sidoarjo. JKMP: Jurnal Kebijakan dan Manajemen Publik, 4(2), 135-150.

Purnomo, R. A. (2016). Dampak relokasi terhadap lingkungan sosial pedagang kaki lima di Pusat Kuliner Pratistha Harsa Purwokerto. Ekuilibrium: Jurnal IImiah Bidang IImu Ekonomi, 11(1), 1-9.

Rahman, A., \& Nurhamlin, N. (2014). Dampak relokasi pedagang kaki lima (PKL) Pasar Jongkok ke MTC Giant Panam terhadap kehidupan sosial ekonomi pedagang. Jurnal Online Mahasiswa Fakultas IImu Sosial Dan IImu Politik Universitas Riau, 1(2).

Raja Nurafiqah Raja Zulkifi, Noor Sulastry Yurni Ahmad, Mohd Azizuddin Mohd Sani, \& Haslina Muhamad. (2018). Impak satira politik terhadap internet trolling di Malaysia. Jurnal Komunikasi: Malaysian Journal of Communication, 34(2), 223-242.

Ramdhani, A., \& Ramdhani, M. A. (2017). Konsep umum pelaksanaan kebijakan publik. Jurnal Publik, 11(1), 1-12.

Ross, M. H. (1993). The management of conflict: Interpretations and interests in comparative perspective. UK: Yale University Press. 
Sidauruk, P. L. (2013). Peranan komunikasi dalam implementasi kebijakan pusat layanan internet kecamatan (Kasus di provinsi kepulauan Bangka Belitung). Jurnal Penelitian Pos dan Informatika, 3(1), 81-113.

Surbakti, R. (1992). Memahami ilmu politik. Jakarta: Grasindo.

Susanto, E. H. (2013). Dinamika komunikasi politik dalam pemilihan umum. Jurnal Kajian Komunikasi, 1(2), 163-172.

Wahab, S. A. (2008). Pengantar analisis kebijakan publik. Malang: Universitas Muhammadiyah Malang Press.

West, R., \& Turner, L. H. (2013). Introducing communication theory: Analysis and application. New York: McGraw-Hill.

Wilson, S., \& Ibrahim, F. (2018). Diplomacy in reporting: The Sulu conflict in East Borneo. Jurnal Komunikasi: Malaysian Journal of Communication, 34(3).

Winarno, B. (2002). Teori dan proses kebijakan publik. Indonesia: Media Pressindo. 